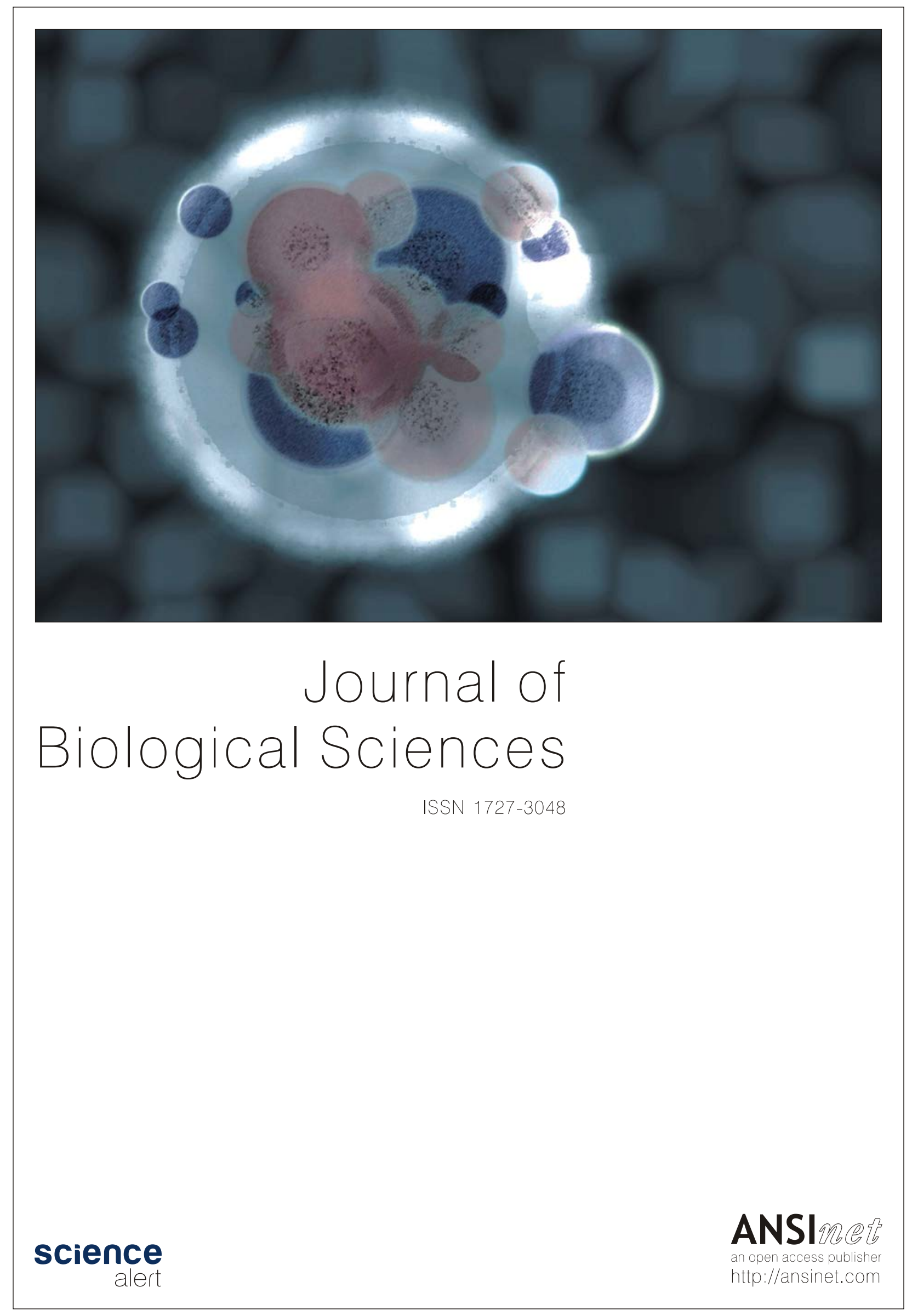




\title{
Research Article \\ Effect of Setting Condition on the Gel Properties of Surimi from Catfish (Clarias gariepinus)
}

\author{
${ }^{1,2}$ Ita Zuraida, ${ }^{2}$ Sri Raharjo, ${ }^{2}$ Pudji Hastuti and ${ }^{2}$ Retno Indrati \\ ${ }^{1}$ Faculty of Fisheries and Marine Science, Mulawarman University, Kampus Gn. Kelua, 75119 Samarinda, Indonesia \\ ${ }^{2}$ Department of Food and Agricultural Product Technology, Faculty of Agricultural Technology, Universitas Gadjah Mada, Jl. Flora, \\ Bulaksumur, 55281 Yogyakarta, Indonesia
}

\section{Abstract}

Background and Objective: Differences in gelling properties may be attributed to the chemical composition and setting conditions at a particular temperature employed during the formation of surimi gels. The aim of this study was to investigate the chemical composition and effect of setting condition on the gel properties of surimi prepared from Clarias gariepinus (local name "lele dumbo"). Materials and Methods: Kamaboko gel was prepared by incubating the surimi sol at $35^{\circ} \mathrm{C}$ prior to heating at $90^{\circ} \mathrm{C}$, while directly heated gel was prepared by heating the sol at $90^{\circ} \mathrm{C}$. Data were subjected to analysis with a one-way ANOVA for comparison of means at a $5 \%$ level of significance. Results: The myofibrillar and sarcoplasmic protein contents were $16.27 \pm 0.23$ and $2.02 \pm 0.06 \mathrm{mg} \mathrm{N} \mathrm{g}^{-1}$ surimi, $^{2}$ respectively. About $40 \%$ of transglutaminase activity was retained in the final surimi. Kamaboko gel showed higher gel strength, hardness and springiness when compared with directly heated gel. However, it had a lower expressible moisture content. Both surimi gels showed no significant difference in the whiteness parameter. Electrophoretic patterns indicated that although myosin heavy chain may undergo polymerisation in both, kamaboko gel and directly heated gel, the extent of polymerisation may be greater in kamaboko gel. Conclusion: The two-step heating involving setting of surimi sol at $35^{\circ} \mathrm{C}$ prior to heating at $90^{\circ} \mathrm{C}$ could enhance gel properties of lele dumbo surimi.

Key words: Setting condition, gelling properties, lele dumbo surimi, endogenous transglutaminase activity

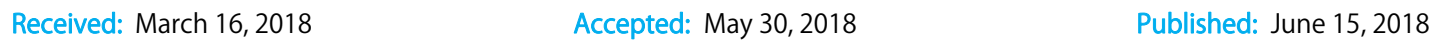

Citation: Ita Zuraida, Sri Raharjo, Pudji Hastuti and Retno Indrati, 2018. Effect of setting condition on the gel properties of surimi from catfish (Clarias gariepinus). J. Biol. Sci., 18: 223-230.

Corresponding Author: Retno Indrati, Department of Food and Agricultural Product Technology, Faculty of Agricultural Technology, Universitas Gadjah Mada, Jl. Flora, Bulaksumur, 55281 Yogyakarta, Indonesia Tel: +62811267259 Fax: +62274589797

Copyright: @ 2018 Ita Zuraida et al. This is an open access article distributed under the terms of the creative commons attribution License, which permits unrestricted use, distribution and reproduction in any medium, provided the original author and source are credited.

Competing Interest: The authors have declared that no competing interest exists.

Data Availability: All relevant data are within the paper and its supporting information files. 


\section{INTRODUCTION}

Surimi is a Japanese term for an intermediate product made from fish or other meat that is produced by washing minced meat with cold water, adding food-grade cryoprotectants as preservatives and then freezing it. It is a primary ingredient for producing many kinds of processed foods especially surimi-based products. One of the most important attributes of surimi is gel strength, which is the main standard for surimi quality ${ }^{1,2}$. Myofibrillar protein mainly myosin is contributes to gel formation and water holding capacity of surimi. The properties of myofibrillar protein are affected by the species, fish freshness and surimi-making process ${ }^{3}$. During heating of surimi paste, myosin can form a 3-dimensional network structure that holds water in a less mobile state.

Surimi gel strength can be improved by setting surimi paste at a low temperature prior to cooking ${ }^{4}$. Application of setting in the surimi sol at different temperature and time can caused the different characteristics of surimi gel ${ }^{5}$. Setting (suwari) phenomenon by pre-incubation of surimi paste at temperatures between 0 and $40^{\circ} \mathrm{C}$ is closely related with polymerization of myosin heavy chain (MHC) catalysed by endogenous transglutaminase (TGase) ${ }^{6,7}$. Endogenous TGase catalyzes the cross-linking reactions between myofibrillar proteins, resulting in a stronger ge ${ }^{8}$. Some researchers have reported that quality of surimi gels subjected to setting are mostly better than directly heated gels. Luo et al. ${ }^{9}$ reported that the breaking force of alaska pollock and common carp surimi gel at $35^{\circ} \mathrm{C}$ was significantly higher than that of surimi prepared with no pre-incubation. Hosseini-Shekarabi et al. also reported that directly heated black mouth croaker surimi gel at $90^{\circ} \mathrm{C}$ had lower gel strength than surimi subjected to two-step heating (pre-incubating surimi paste at $40^{\circ} \mathrm{C}$, followed by heating at $90^{\circ} \mathrm{C}$ ).

Catfish (Clarias gariepinus), which has the local name "lele dumbo", is one of the leading commodities of Indonesian aquaculture. The production of cultured catfish has reached $20 \%$ of the total aquaculture production ${ }^{10}$. Previous study analyzed amino acid profiles, protein composition and endogenous TGase activity of lele dumbo muscle. They reported that lele dumbo can be used as an alternative raw material for surimi production ${ }^{11}$. Study conducted by Wijayanti et al.12, who reported the effect of leaching times on the water holding capacity, $\mathrm{pH}$, texture and folding test of catfish (Clarias gariepinus) surimi. However, information about the effect of setting condition on the gel properties of surimi from lele dumbo related to endogenous TGase activity of lele dumbo surimi is still limited. The surimi-making process may alter the chemical composition of lele dumbo surimi especially myofibrillar and sarcoplasmic protein composition and endogenous TGase activity. Therefore, the objective of this study was to investigate the chemical composition of lele dumbo surimi and effect of setting condition (two-step and directly heating) on the gel strength, texture profile, expressible moisture content, whiteness and protein pattern of surimi and surimi gel with SDS-PAGE.

\section{MATERIALS AND METHODS}

This study was conducted from March to October, 2017. It starts from sample preparation for surimi production and its chemical composition analysis, followed by the formation of surimi gel under different setting condition and its gel properties analysis.

Lele dumbo (Clarias gariepinus, weight: 150-200 g) was purchased from a fish farm in Boyolali, Central Java, Indonesia and was transported to the laboratory alive. The gutted lele dumbo was washed with cold water $\left(4^{\circ} \mathrm{C}\right)$, then filleted by hand. Fillets were minced using a mincer with a hole diameter of $5 \mathrm{~mm}$ and was then kept in ice till surimi preparation. CBZ-glutaminyl-glycine, hydroxylamine, glutathione and L-glutamic acid $\gamma$-monohydroxamate were purchased from Sigma Chemical Co. (St. Louis, MO, USA).All chemicals for electrophoresis were purchased from Bio-Rad Laboratories (Hercules, CA, USA). All other reagents and chemicals were of analytical grade.

Surimi and surimi gel preparation: Surimi was prepared according to the method of Luo et al. ${ }^{13}$ with slight modifications. The washing was performed with a 1:3 (w/v) ratio of mince to cold distilled water $\left(4^{\circ} \mathrm{C}\right)$ and continuously stirred for $10 \mathrm{~min}$ in wash tanks. The washing process was repeated twice and $0.3 \% \mathrm{NaCl}$ was added during the last washing. The washed mince was filtered through four layers of cheese-cloth and dewatered in a pressing machine. To the dewatered mince, $4 \%$ sucrose and $4 \%$ sorbitol were added and mixed for $5 \mathrm{~min}$ in a food processor at a temperature below $10^{\circ} \mathrm{C}$. Surimi were kept at $-18^{\circ} \mathrm{C}$ until further use.

To prepare the gels, the frozen surimi was thawed at $5^{\circ} \mathrm{C}$ overnight in a cold room. Then, the moisture content of the surimi was adjusted to $80 \%$ and mixed with $3 \% \mathrm{NaCl}$ for 5 min in a food processor (Model HR7627, Philips, China). The raw paste was packed into polyethylene casing having a diameter of $3 \mathrm{~cm}$. The sol pre-incubated at $35^{\circ} \mathrm{C}$ for $30 \mathrm{~min}$, followed by heating at $90^{\circ} \mathrm{C}$ for $20 \mathrm{~min}$, was referred to as 'Kamaboko gel (KG)'. A directly heated gel (HG) was prepared 
by heating the sol at $90^{\circ} \mathrm{C}$ for $20 \mathrm{~min}$. All the heated gels were cooled immediately in ice water for $30 \mathrm{~min}$ and were stored at $4^{\circ} \mathrm{C}$.

Chemical composition: Moisture, ash, protein and fat contents of surimi was determined according to the AOAC methods ${ }^{14}$. Myofibrillar and sarcoplasmic proteins of surimi were fractionated according to the method of Hashimoto et al. ${ }^{15}$ as described in a previous report ${ }^{11}$. Myofibrillar and sarcoplasmic fractions were analyzed for its nitrogen content using the Kjeldahl method ${ }^{14}$. The crude TGase extract of surimi was prepared by the method of Binsi and Shamasundar ${ }^{6}$ and the TGase activity of surimi was determined by hydroxamate method according to the procedure of Folk and Cole $^{16}$, both as described by Zuraida et al. ${ }^{11}$.

\section{Gel strength and texture profile analysis (TPA)} measurement: Gel strength and texture profile of the gels was performed using a LFRA 4500 texture analyzer (Brookfield, Middleboro, MA, USA) according to the method of Shi et al.2 and Yin and Park ${ }^{8}$ with slight modifications, respectively. Gels were equilibrated and evaluated at room temperature $\left(28-30^{\circ} \mathrm{C}\right)$. Cylinder-shaped surimi gels with length $2.5 \mathrm{~cm}$ and diameter $3.0 \mathrm{~cm}$ were prepared. Breaking force $(\mathrm{g})$ and breaking distance $(\mathrm{mm})$ were measured with a cylindrical plunger (diameter $5.0 \mathrm{~mm}$, test speed $1.0 \mathrm{~mm} \mathrm{~min}{ }^{-1}$ ). Gel strength $(\mathrm{g} \mathrm{cm})$ was determined by multiplying breaking force with breaking distance. For texture profile, gel samples were subjected to two-cycle compression using a cylindrical plunger $5.0 \mathrm{~mm}$ in diameter at a deformation rate of $1.0 \mathrm{~mm} \mathrm{~min}^{-1}$. The parameters determined were hardness, chewiness, gumminess, springiness and cohesiveness.

Expressible moisture content: Expressible moisture content was measured according to the method of Rawdkuen et al. ${ }^{17}$ with a slight modification. A gel sample with a thickness of $0.5 \mathrm{~cm}$ was weighed ( $\mathrm{X}$ in grams) and placed between one piece of Whatman filter paper no. 1 at the top and two pieces of Whatman filter paper at the bottom. A standard weight of $5 \mathrm{~kg}$ was placed on the top of the sample and maintained for $2 \mathrm{~min}$ and then the sample was removed and weighed again ( $Y$ in grams). Expressible moisture content was calculated and expressed as a percentage of sample weight as follows:

$$
\text { Expressible moisture content }(\%)=\frac{X-Y}{X} \times 100
$$

Whiteness: Surimi gel colour was determined using a CR-10 plus color reader (Konica Minolta, INC., Japan). L* (lightness), $a^{*}$ (redness/greenness) and $b^{*}$ (yellowness/blueness) were measured and whiteness was calculated using the following Eq.:

$$
\text { Whiteness }=100-\left[\left(100-L^{*}\right)^{2}+a^{* 2}+b^{* 2}\right]^{1 / 2}
$$

Sodium dodecyl sulphate-polyacrylamide gel electrophoresis (SDS-PAGE): Protein patterns of surimi and surimi gel were visualised by SDS-PAGE according to the method of Laemmli ${ }^{18}$. To prepare the protein sample, $27 \mathrm{~mL}$ of $5 \%(\mathrm{w} / \mathrm{v})$ hot $\operatorname{SDS}\left(85^{\circ} \mathrm{C}\right)$ solution was added to the sample $(3 \mathrm{~g})$. The mixture was homogenised for $1 \mathrm{~min}$. The homogenate was incubated at $85^{\circ} \mathrm{C}$ for $1 \mathrm{~h}$ to dissolve total proteins, followed by centrifugation at $8000 \mathrm{rpm}$ for $5 \mathrm{~min}$ at room temperature (Eppendorf Centrifuge 5417 R, Hamburg, Germany). Protein concentration was determined according to the method of Lowry et $a / .^{19}$. The supernatants were mixed at 1:1 $(\mathrm{v} / \mathrm{v})$ ratio with the sample buffer $(0.5 \mathrm{M}$ Tris- $\mathrm{HCl} \mathrm{pH} 6.8$, containing $25 \%$ glycerol, $10 \%$ SDS, $0.5 \%$ bromophenol blue and 5\% $\beta M E$ ) and boiled for $3 \mathrm{~min}$. The samples (20 $\mu \mathrm{g}$ protein) were loaded into the polyacrylamide gel ( $8 \%$ running gel and 5\% stacking gel) and subjected to electrophoresis at a constant current of $200 \mathrm{~V}$ per gel using a Mini Protean unit (Bio-Rad Laboratories, Inc., Richmond, CA, USA). After electrophoresis, the gel was stained with $0.05 \%(\mathrm{w} / \mathrm{v})$ Coomassie blue R-250 in 15\% (v/v) methanol and 5\% (v/v) acetic acid and destained with $30 \%(\mathrm{v} / \mathrm{v})$ methanol and $10 \%(\mathrm{v} / \mathrm{v})$ acetic acid. A protein marker (Precision plus protein standards dual color, 10-250 kDa, Bio-Rad Laboratories, Inc., Richmond, CA, USA) was used to estimate the molecular weight of proteins.

Statistical analysis: All analyses were performed in triplicate. Data were subjected to analysis with a one-way ANOVA for comparison of means at a $5 \%$ level of significance. The statistical analysis was carried out using SPSS software version 20 (SPSS Inc., Chicago, IL, USA).

\section{RESULTS}

Chemical composition of lele dumbo surimi: The chemical composition of lele dumbo surimi was presented in Table 1. The moisture content was $77.57 \pm 0.23 \%$ wet weight. Ash, protein and fat content were $2.06 \pm 0.09,58.28 \pm 0.16$ and $3.66 \pm 0.13 \%$ dry weight, respectively. The myofibrillar 


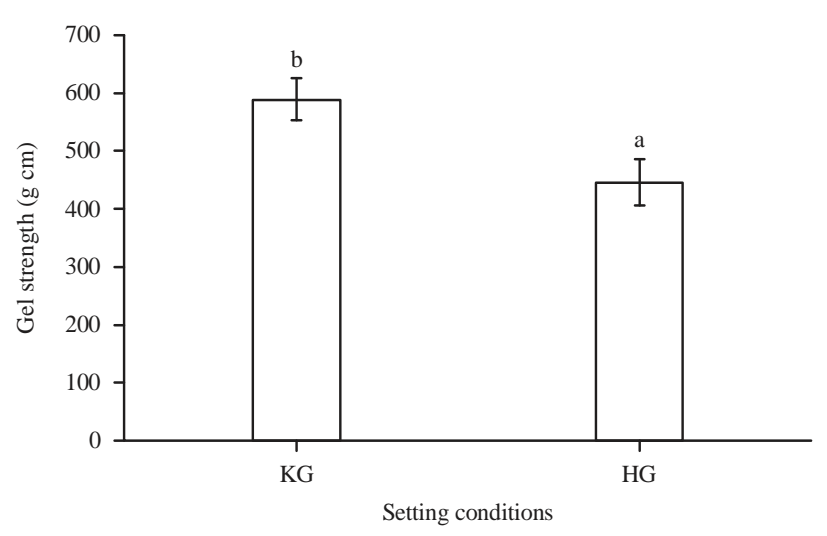

Fig. 1: Gel strength of different gels made from lele dumbo surimi: Kamaboko gel (KG) and directly heated gel (HG)

Bars indicate the standard deviations and value with different letters indicate statistically significant differences $(p<0.05)$

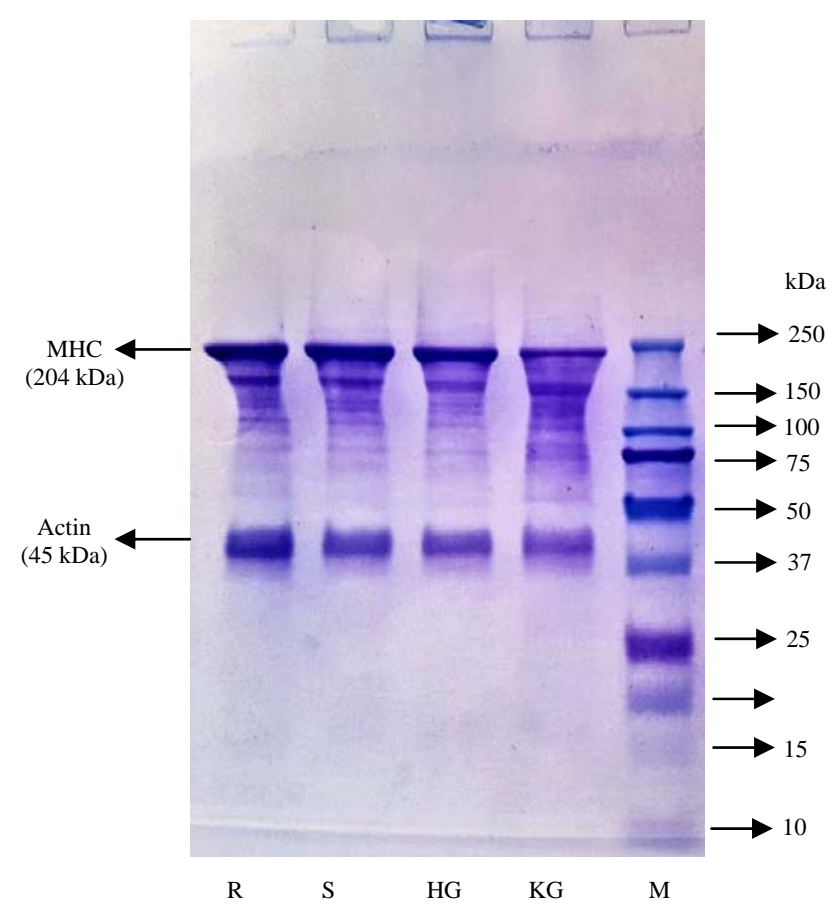

Fig. 2: SDS-PAGE patterns of lele dumbo surimi gels using different setting conditions

R: Raw material (lele dumbo muscle), S: Surimi, HG: Directly heated gel, KG: Kamaboko gel with setting at $35^{\circ} \mathrm{C}$, M: Marker and sarcoplasmic protein content were $16.27 \pm 0.23$ and $2.02 \pm 0.06 \mathrm{mg} \mathrm{N} \mathrm{g}^{-1}$ surimi, respectively. TGase activity was $0.07 \pm 0.01 \mathrm{U} \mathrm{mL}^{-1}$.

Gel strength: Gel strength of KG and HG were 591.19 and $447.98 \mathrm{~g} \mathrm{~cm}$, respectively. There was a significant difference for gel strength between kamaboko gel and directly heated gel (Fig. 1, p<0.05).

Texture profile analysis (TPA): Texture profile analysis of lele dumbo surimi gel was presented in Table 2 . There were a significant difference $(p<0.05)$ for hardness, chewiness, gumminess and springiness between KG and HG. In terms of cohesiveness, there was no significant difference ( $p>0.05)$ between the two surimi gels prepared under different setting conditions.

Expressible moisture content and whiteness: Expressible moisture content and whiteness of lele dumbo surimi gel was presented in Table 3. There was a significant difference for expressible moisture content between KG and HG $(p<0.05)$. Meanwhile, there was no significant difference $(p>0.05)$ for whiteness between $\mathrm{KG}$ and $\mathrm{HG}$.

Protein pattern: SDS-PAGE pattern of lele dumbo muscle, surimi and surimi gels prepared under different setting conditions and subjected to reducing conditions were shown in Fig. 2. Electrophoretic patterns indicated that myosin heavy chain (MHC; $204 \mathrm{kDa}$ ) was the major protein with highest band intensity in all samples, especially in lele dumbo muscle (R) and surimi (S). The MHC band markedly decreased in surimi gels prepared under different setting conditions. However, MHC was retained more in $\mathrm{HG}$.

Table 1: Chemical composition of lele dumbo surimi

\begin{tabular}{lr}
\hline Component & \multicolumn{1}{c}{ Values } \\
\hline Moisture (\% wet weight) & $77.57 \pm 0.23^{*}$ \\
Ash (\% dry weight) & $2.06 \pm 0.09$ \\
Crude protein (\% dry weight) & $58.28 \pm 0.16$ \\
Crude fat (\% dry weight) & $3.66 \pm 0.13$ \\
Myofibrillar protein ( $\mathrm{mg} \mathrm{N} \mathrm{g}^{-1}$ surimi) & $16.27 \pm 0.23$ \\
Sarcoplasmic protein $\left(\mathrm{mg} \mathrm{N}^{-1}\right.$ surimi) & $2.02 \pm 0.06$ \\
Transglutaminase activity $\left(\mathrm{U} \mathrm{mL}^{-1}\right)$ & $0.07 \pm 0.01$ \\
\hline *Values are given as the Mean $+\mathrm{SD}$ of the triplicate measurements
\end{tabular}

*Values are given as the Mean \pm SD of the triplicate measurements

Table 2: Texture profile analysis of surimi gels made from lele dumbo under different setting conditions

\begin{tabular}{llcccc}
\hline Sample & Hardness $(\mathrm{g})$ & Chewiness $(\mathrm{g} \mathrm{mm})$ & Gumminess $(\mathrm{g})$ & Springiness $(\mathrm{mm})$ & Cohesiveness \\
\hline KG & $565.00 \pm 13.23^{\mathrm{a} *}$ & $2217.79 \pm 16.23^{\mathrm{a}}$ & $246.70 \pm 8.43^{\mathrm{a}}$ & $8.69 \pm 0.66^{\mathrm{a}}$ & $0.42 \pm 0.06^{\mathrm{a}}$ \\
HG & $426.17 \pm 29.27^{\mathrm{b}}$ & $1281.95 \pm 32.59^{\mathrm{b}}$ & $171.01 \pm 13.27^{\mathrm{b}}$ & $7.55 \pm 0.42^{\mathrm{b}}$ & $0.39 \pm 0.01^{\mathrm{a}}$ \\
\hline
\end{tabular}

*Values are given as the Mean \pm SD of the triplicate measurements for kamaboko gel (KG) and directly heated gel (HG). Different superscripts in the same column indicate a significant difference $(p<0.05)$ 
Table 3: Expressible moisture content and whiteness of surimi gels made from lele dumbo under different setting conditions

\begin{tabular}{lcc}
\hline Sample & Expressible moisture content (\%) & Whiteness \\
\hline Kamaboko gel (KG) & $5.88 \pm 0.55^{\mathrm{a} *}$ & $74.17 \pm 0.26^{\mathrm{a}}$ \\
Directly heated gel $(\mathrm{HG})$ & $7.13 \pm 0.22^{\mathrm{b}}$ & $74.03 \pm 0.43^{\mathrm{a}}$ \\
\hline *Values are given as the Mean \pm SD of the triplicate measurements. Different \\
superscripts in the same column indicate a significant difference $(p<0.05)$
\end{tabular}

\section{DISCUSSION}

Gel forming ability of surimi can be affected by their chemical composition especially concentration of myofibrillar versus sarcoplasmic proteins and endogenous TGase activity in surimi as well as application of setting temperatures used to improve gel properties. The surimi-making process involves repeated washing of fish mince with chilled water to remove sarcoplasmic proteins, connective tissue, enzymes, other nitrogenous compounds, fat, blood, pigments and other impurities that could reduce surimi quality, but retain the myofibrillar proteins ${ }^{20}$. The chemical composition of lele dumbo surimi changed after washing. The moisture content was higher, while ash, protein and fat content were lower than in lele dumbo muscle as reported in a previous report ${ }^{11}$. An increase in surimi moisture content could be associated with the reduction of protein and fat content. This result was supported by the findings of Wijayanti et al. ${ }^{12}$, who reported that two washing cycles could increase the moisture content of surimi by $6 \%$. The decrease in protein content probably was due to the solubility of sarcoplasmic protein in water during the washing process. The reduction in fat and ash content after washing could be attributed to the effective removal of lipid substances and the water-soluble minerals ${ }^{21}$.

The myofibrillar and sarcoplasmic protein content of lele dumbo surimi were lower than that of lele dumbo muscle as reported by Zuraida etal!" ${ }^{1}$. However, concentration of myofibrillar versus sarcoplasmic proteins in lele dumbo surimi ( 85.41 vs. $10.60 \%$ from total protein) was higher than that of lele dumbo muscle ( $69.24 \mathrm{vs.} 18.30 \%)$. The total protein is the sum of water-soluble sarcoplasmic proteins including the non-protein nitrogen, myofibrillar protein and the stroma proteins of lele dumbo surimi $\left(19.05 \mathrm{mg} \mathrm{N} \mathrm{g}^{-1}\right.$ surimi, data not shown). The surimi-making process retained the myofibrillar protein and simultaneously reduced the sarcoplasmic protein content. Park ${ }^{22}$ reported that the reduction of sarcoplasmic proteins, in turn, concentrated the myofibrillar proteins, thus enhancing the gelling properties of surimi. The myofibrillar proteins especially myosin heavy chain (MHC) is responsible for the textural properties of surimi gel through its ability to form a 3-dimensional gel structure ${ }^{23}$.
On the other hand, Hemung and $\mathrm{Chin}^{24}$ reported that sarcoplasmic proteins inhibit the gelation process of surimi gel.

TGase is an endogenous enzyme that catalyzes the cross-linking of myosin heavy chain (MHC) during setting of surimi gel, resulting in the formation of non-disulfide covalent bonds $\varepsilon$-( $\gamma$-glutamyl)-lysine, which increases the gel strength and water holding capacity ${ }^{6,25}$. TGase activity of lele dumbo surimi was $0.07 \mathrm{U} \mathrm{mL} \mathrm{L}^{-1}$, lower than the TGase activity of lele dumbo muscle ${ }^{11}$. TGase activity of surimi has a high variability and is the effect of a combination of factors, such as the natural content of the enzyme in fish species, surimi manufacturing process and the number of reactive glutamine residues on the myosin molecules ${ }^{26}$.Yongsawatdigul et al.27 reported that the washing cycles removed $56 \%$ of the endogenous TGase activity from threadfin bream muscle and only about $44 \%$ of the TGase activity was retained in the final surimi. This result was similar to the $40 \%$ TGase activity retained in the final lele dumbo surimi analyzed in this study.

Different setting conditions of surimi gel resulted in different gelling properties. Kamaboko gel (KG) prepared with two-step heating protocol involving setting at $35^{\circ} \mathrm{C}$ prior to heating at $90^{\circ} \mathrm{C}$, exhibited higher gel strength compared to the directly heated gel $(\mathrm{HG})$. The result indicated that protein aggregation stabilised by various bonds was stronger in kamaboko gels. Setting of surimi gel at different temperatures before heating can affect the gel textural characteristics. Several researchers have reported the superior textural characteristics of kamaboko gel compared with directly heated gel e.g. yellow stripe trevally surimi ${ }^{1}$ and black mouth croaker surimi $i^{7}$. Setting phenomenon, plays an important role in cross-linking of myosin heavy chain and has been associated with endogenous TGase activity ${ }^{28}$. Thus, the higher gel strength of kamaboko gel could be attributed to the endogenous TGase activity in lele dumbo surimi. TGase could enhance myosin cross-linking via the formation of $\epsilon$-( $\gamma$-glutamyl)-lysine linkages, a type of non-disulfide covalent bonds. Therefore, utilization of an appropriate setting temperature could enhance the formation of non-disulfide covalent bonds. In HG, cross-linking of MHC induced by endogenous TGase may be less.

Kamaboko gel prepared with two-step heating process were harder, chewier, gummier and more elastic than directly heated gel. The higher hardness and springiness values of kamaboko gel are due to the higher gel strength. This finding was consistent with a previous study reported by Hosseini-Shekarabi et al. that the hardness, springiness (elasticity) and gumminess of kamaboko gel were higher than 
those of directly heated gel. Benjakul and Visessanguan ${ }^{5}$ also reported that the existence of endogenous TGase in surimi could enhance the hardness and elasticity of surimi gel during setting. Therefore, the results suggested that pre-incubation at $35^{\circ} \mathrm{C}$ is more suitable for gel formation of lele dumbo surimi.

Kamaboko gel set at $35^{\circ} \mathrm{C}$ showed lower expressible moisture content compared to directly heated gel, indicating higher water holding capacity of the kamaboko gel. From the results it can be observed that the lower expressible moisture content was in correlation with the higher gel strength (Fig. 1) and hardness of surimi gel (Table 2). Rapid unfolding of proteins during direct heating results in more intense coagulation ${ }^{29}$. Niwa ${ }^{3}$ reported that rapid unfolding of proteins released more water from the gel network resulting in irregular dispersion of proteins. Arfat and Benjakul' also reported that kamaboko gel from yellow stripe trevally surimi exhibited lower expressible moisture content than directly heated gel.

Moreover, whiteness is one of the important characteristic for determining the quality and general appearance and acceptability of surimi gel ${ }^{30,22}$. The results showed that setting conditions had no effect on whiteness of lele dumbo surimi gels. This was contradictory to a previous study reported by Arfat and Benjakul ${ }^{1}$ and Hosseini-Shekarabi et al. ${ }^{7}$ which showed that directly heated gel exhibited higher whiteness compared to kamaboko gel $(p<0.05)$. However, the whiteness of kamaboko gel prepared from lele dumbo surimi was inferior to that obtained from other freshwater fish surimi gel such as grass carp surimi ${ }^{31}$, but superior to that reported for common carp surimi ${ }^{32}$. Cortez-Vega et al.33, Kang et al. ${ }^{34}$ and Chaijan et al. ${ }^{35}$ reported that differences in whiteness of surimi gel may be related to fish species and processing parameters, the sarcoplasmic protein removal efficiency and lipid content of fish muscle.

Electrophoretic patterns indicated that although MHC may undergo polymerisation in both, $\mathrm{KG}$ and $\mathrm{HG}$, the extent of polymerisation may be greater in KG. This was attributed to the endogenous TGase activity in lele dumbo surimi that promotes the cross-linking of MHC. These results are consistent with a previous study, which found that maximum polymerisation occurred in kamaboko gel ${ }^{1,7}$. Benjakul and Visessanguan $^{5}$ also reported that decrease in MHC after heating may be due to the presence of TGase in surimi gel that enables protein cross-linking during setting. Decrease in $\mathrm{MHC}$ as seen on SDS-PAGE correlated with the increased gel strength, hardness, elasticity and water holding capacity of kamaboko gel, indicating that two-step heating clearly affected the gel properties of lele dumbo surimi.

\section{CONCLUSION}

The application of different setting conditions significantly affected the gel properties of lele dumbo surimi. Kamaboko gel exhibited higher gel strength, hardness, springiness (elasticity) and water holding capacity compared to the directly heated gel. The higher polymerisation in kamaboko gel was attributed to the endogenous TGase activity in lele dumbo surimi that promotes the cross-linking of myosin heavy chain. Therefore, two-step process with setting of surimi sol at $35^{\circ} \mathrm{C}$ prior to heating at $90^{\circ} \mathrm{C}$ is important to enhance gel properties of lele dumbo surimi.

\section{SIGNIFICANCE STATEMENT}

This study shows that concentration of myofibrillar versus sarcoplasmic proteins, TGase activity and setting conditions are some factors affecting the gelling properties of lele dumbo surimi. The two-step heating involving setting of surimi sol at $35^{\circ} \mathrm{C}$ prior to heating at $90^{\circ} \mathrm{C}$ could enhance gel properties of lele dumbo surimi.

\section{ACKNOWLEDGMENT}

The authors would like to thank the Directorate General of Research and Development Strengthening, Ministry of Research, Technology and Higher Education of the Republic of Indonesia for their financial support to this research via Beasiswa Pendidikan Pascasarjana Dalam Negeri/BPPDN) with grant number 2197.8/E4.4/2014.

\section{REFERENCES}

1. Arfat, Y.A. and S. Benjakul, 2012. Gelling characteristics of surimi from yellow stripe trevally (Selaroides leptolepis). Int. Aquat. Res., Vol. 4. 10.1186/2008-6970-4-5

2. Shi, J., Y. Luo, H. Shen and Z. Li, 2014. Gel properties of surimi from silver carp (Hypophthalmichthys molitrix): Effects of whey protein concentrate, $\mathrm{CaCl}_{2}$ and setting condition. J. Aquat. Food Prod. Technol., 23: 489-497.

3. Niwa, E., 1992. Chemistry of Surimi Gelation. In: Surimi Technology, Lanier, T.C. and C.M. Lee (Eds.)., Marcell Dekker, New York.

4. Van Phu, N., K. Morioka and Y. Itoh, 2010. Gel-forming characteristics of surimi from white croaker under the inhibition of the polymerization and degradation of protein. J. Biol. Sci., 10: 432-439. 
5. Benjakul, S. and W. Visessanguan, 2003. Transglutaminasemediated setting in bigeye snapper surimi. Food Res. Int., 36: 253-266.

6. Binsi, P.K. and B.A. Shamasundar, 2012. Purification and characterisation of transglutaminase from four fish species: Effect of added transglutaminase on the viscoelastic behaviour of fish mince. Food Chem., 132: 1922-1929.

7. Hosseini-Shekarabi, S.P., S.E. Hosseini, M. Soltani, A. Kamali and T. Valinassab, 2015. Effect of heat treatment on the properties of surimi gel from black mouth croaker (Atrobucca nibe). Int. Food Res. J., 22: 363-371.

8. Yin, T. and J.W. Park, 2015. Optimum processing conditions for slowly heated surimi seafood using protease-laden Pacific whiting surimi. LWT-Food Sci. Technol., 63: 490-496.

9. Luo, Y.K., R.Kuwahara, M. Kaneniwa, Y. Murata and M. Yokoyama, 2001. Comparison of gel properties of surimi from alaska pollock and three freshwater fish species: Effects of thermal processing and protein concentration. J. Food Sci., 66: 548-554.

10. Anonymous, 2016. Statistical data of aquaculture fishery in Indonesia. Indonesian Ministry of Marine Affairs and Fisheries, Indonesia.

11. Zuraida, I., S. Raharjo, P. Hastuti and R. Indrati, 2017. Catfish (Clarias gariepinus): A potential alternative raw material for surimi production. Pak. J. Nutr., 16: 928-934.

12. Wijayanti, I., J. Santoso and A.M. Jacoeb, 2012. The effect of leaching times on the gel properties of catfish (Clarias gariepinus) Surimi. J. Saintek Perikanan, 8: 32-37.

13. Luo, Y., H. Shen, D. Pan and G. Bu, 2008. Gel properties of surimi from silver carp (Hypophthalmichthys molitrix) as affected by heat treatment and soy protein isolate. Food Hydrocoll., 22: 1513-1519.

14. AOAC., 1995. The Official Method of Analysis of the Association of Official Analytical Chemists. 16th Edn., Association of Official Analytical Chemists, Arlington, VA, USA.

15. Hashimoto, K., S. Watabe, M. Kono and M. Shiro, 1979. Muscle protein composition of sardine and mackerel. Bull. Japanese Soc. Sci. Fish., 45: 1435-1441.

16. Folk, J.E. and P.W. Cole, 1966. Mechanism of action of guinea pig liver transglutaminase I. Purification and properties of the enzyme: Identification of a functional cysteine essential for activity. J. Biol. Chem., 241: 5518-5525.

17. Rawdkuen, S., S. Sai-Ut, S. Khamsorn, M. Chaijan and S. Benjakul, 2009. Biochemical and gelling properties of tilapia surimi and protein recovered using an acid-alkaline process. Food Chem., 112: 112-119.

18. Laemmli, U.K., 1970. Cleavage of structural proteins during the assembly of the head of bacteriophage T4. Nature, 227: 680-685.
19. Lowry, O.H., N.J. Rosebrough, A.L. Farr and R.J. Randall, 1951. Protein measurement with the folin phenol reagent. J. Biol. Chem., 193: 265-275.

20. Zhang, L., Q. Li, J. Shi, B. Zhu and Y. Luo, 2018. Changes in chemical interactions and gel properties of heat-induced surimi gels from silver carp (Hypophthalmichthys molitrix) fillets during setting and heating: Effects of different washing solutions. Food Hydrocolloids, 75: 116-124.

21. Hossain, M.I., M.M. Kamal, F.H. Shikha and A.M.S. Hoque, 2004. Effect of washing and salt concentration on the gel forming ability of two tropical fish species. Int. J. Agric. Biol., 6: 762-766.

22. Park, J.W., 2014. Surimi and Surimi Seafood. 3rd Edn., Taylor and Francis, Boca Raton, Fla., pp: 58-61.

23. Sun, X.D. and R.A. Holley, 2011. Factors influencing gel formation by myofibrillar proteins in muscle foods. Comprehensive Rev. Food Sci. Food Safety, 10: 33-51.

24. Hemung, B.O. and K.B. Chin, 2013. Effects of fish sarcoplasmic proteins on the properties of myofibrillar protein gels mediated by microbial transglutaminase. LWT-Food Sci. Technol., 53: 184-190.

25. Zhu, Z., T.C. Lanier, B.E. Farkas and B. Li, 2014. Transglutaminase and high pressure effects on heat-induced gelation of alaska pollock (Theragra chalcogramma) surimi. J. Food Eng., 131: 154-160.

26. Lanier, T.C., J. Yongsawatdigul and P. Carvajal-Rondanelli, 2014. Surimi Gelation Chemistry. In: Surimi and Surimi Seafood, Park, J.W. (Ed.)., 3rd Edn., Taylor and Francis Group, Boca Raton, Fla., pp: 130-131.

27. Yongsawatdigul, J., P. Piyadhammaviboon and K. Singchan, 2006. Gel-forming ability of small scale mud carp (Cirrhiana microlepis) unwashed and washed mince as related to endogenous proteinases and transglutaminase activities. Eur. Food Res. Technol., Vol. 223. 10.1007/s00217-006-0266-4.

28. Paker, I. and K.E. Matak, 2015. Impact of sarcoplasmic proteins on texture and color of silver carp and alaska pollock protein gels. LWT-Food Sci. Technol., 63: 985-991.

29. Chaijan, M., W. Panpipat and S. Benjakul, 2010. Physicochemical properties and gel-forming ability of surimi from three species of mackerel caught in Southern Thailand. Food Chem., 121: 85-92.

30. Benjakul, S., W. Visessanguan and Y. Kwalumtharn, 2004. The effect of whitening agents on the gel-forming ability and whiteness of surimi. Int. J. Food Sci. Technol., 39: 773-781.

31. Yang, Z., W. Wang, H. Wang and Q. Ye, 2014. Effects of a highly resistant rice starch and pre-incubation temperatures on the physicochemical properties of surimi gel from grass carp (Ctenopharyn Odon Idellus). Food Chem., 145: 212-219. 
32. Luo, Y., R. Kuwahara, M. Kaneniwa, Y. Murata and M. Yokyama, 2004. Effect of soy protein isolate on gel properties of Alaska Pollock and common carp surimi at different setting conditions. J. Sci. Food Agric., 84: 663-671.

33. Cortez-Vega, W.R., G.G. Fonseca and C. Prentice, 2012. Comparisons of the properties of whitemouth croaker (Micropogonias furnieri) surimi and mechanically deboned chicken meat surimi-like material. Food Nutr. Sci., 3: 1480-1483.
34. Kang, E.J., A.L. Hunt and J.W. Park, 2008. Effects of salinity on physicochemical properties of Alaska pollock surimi after repeated freeze-thaw cycles. J Food Sci., 73: 347-355.

35. Chaijan, M., S. Benjakul, W. Visessanguan and C. Faustman, 2004. Characteristics and gel properties of muscles from sardine (Sardinella gibbosa) and mackerel (Rastrelliger kanagurta) caught in Thailand. Food Res. Int., 37: 1021-1030. 